\title{
Targeted phototherapy
}

\section{Fototerapia celowana}

\author{
Zonun Sanga
}

Department of Skin and VD, RNT Medical College, Udaipur, India

Przegl Dermatol 20I5, 102, 45-50

DOI: |0.5 | |4/dr.20|5.4920 |

\section{KEY WORDS:}

conventional phototherapy, targeted phototherapy, excimer laser, intense pulse light system, photodynamic therapy, ultraviolet light.

SŁOWA KLUCZOWE:

fototerapia tradycyjna, fototerapia celowana, laser ekscymerowy, system intensywnego światła pulsowego, terapia fotodynamiczna, promieniowanie ultrafioletowe.

ADDRESS FOR CORRESPONDENCE: Dr Zonun Sanga

Department of Skin and VD

RNT Medical College

Udaipur, Rajasthan 313001, India

E-mail: jrkos04@gmail.com

\begin{abstract}
Conventional phototherapy uses a whole body cabinet or body part machines for the hand, foot or scalp. It has many disadvantages, due to which new phototherapy techniques have been developed. These new techniques are called targeted phototherapy. They include excimer laser, the intense pulse light (IPL) system, photodynamic therapy, and an ultraviolet (UV) light source with a sophisticated delivery system which is easy to operate by hand. The mechanisms of action of targeted phototherapy systems are similar to those in conventional UVB/UVA therapy. They have many advantages including lower risk of side effects, avoidance of exposure of unnecessary sites, faster response, and shorter duration of treatment. But they also have disadvantages such as high costs and inability to use them for extensive areas. This review article discusses targeted phototherapy, its mechanisms of action, and advantages and disadvantages in comparison to conventional phototherapy.
\end{abstract}

\section{STRESZCZENIE}

W konwencjonalnej fototerapii wykorzystuje się kabiny umożliwiające naświetlanie całego ciała lub urządzenia do naświetlania fragmentów skóry, takich jak dłonie, stopy czy okolice owłosionej skóry głowy. $\mathrm{Z}$ powodu wielu niedoskonałości metod konwencjonalnych wprowadzono nowe techniki fototerapii, określane jako fototerapia celowana. Należą do nich: laser ekscymerowy, system intensywnego światła pulsowego (ang. intense pulse light - IPL), terapia fotodynamiczna i inne źródła promieniowania ultrafioletowego wymagające prostej obsługi manualnej. Działanie fototerapii celowanej jest podobne do konwencjonalnej terapii UVB/UVA. Fototerapia celowana ma wiele zalet: mniejsza szansa wystąpienia działań niepożądanych, unikanie naświetlania niezajętych okolic skóry, szybsza odpowiedź na terapię i krótszy czas leczenia. Ograniczeniem terapii celowanej jest wysoki koszt takiego leczenia oraz brak możliwości stosowania na duże powierzchnie skóry. W artykule omówiono metodę terapii celowanej, mechanizmy jej działania oraz jej zalety i wady w porównaniu z konwencjonalną fototerapią. 


\section{INTRODUCTION}

Phototherapy is a therapeutic strategy in dermatology for treating several skin diseases. Conventional phototherapy uses a whole body cabinet or body part machine such as hand, foot or scalp machines $[1,2]$. It includes broadband ultraviolet $B(U V B)$ therapy, ultraviolet A (UVA) therapy, SUP or selective ultraviolet phototherapy (310-318) therapy, narrowband UVB (311 nm), and ultraviolet A1 (UVA1) therapy. Phototherapy is used for a wide variety of skin diseases. There has been considerable progress in cellular and cutaneous photobiology leading to improved understanding of different photodermatoses and their treatment. However, the developments in phototherapy have been comparatively slow, as reflected in a recent publication stating that "developments in phototherapy have not kept pace with scientific progress, as has been the case with radiotherapy" [3].

Conventional phototherapy has many disadvantages including exposing uninvolved areas, a slow delivery system and lengthy treatment sessions, multiple and frequent visits to the clinic, difficulty in treating certain areas (such as genitalia, oral mucosa, ear, etc), difficulty in treating children who may feel intimidated by the large machines, and the large office space required to house the bulky machines [4]. Due to these disadvantages of conventional phototherapy, a new phototherapy technique was developed to overcome these problems. This technique was called targeted phototherapy and is also known as concentrated phototherapy, focused phototherapy, microphototherapy and localized phototherapy. This review mainly focuses on this newer technique called targeted phototherapy.

Targeted phototherapy is defined as a therapeutic method using a device that delivers laser light or ultraviolet light spectrum of a specific wavelength focused on specific body areas or lesions. This definition includes different technologies used, such as excimer laser, intense pulse light system (IPL), photodynamic therapy, and ultraviolet (UV) light source with a sophisticated delivery system which is easy to operate by hand [3].

\section{MECHANISM OF ACTION}

Most phototherapy devices (laser or non-laser type) emit radiation in the UVB range, with peak emission in the narrowband wavelength (around 308-311 nm), while some light-based nonlaser machines emit UVA radiation also. Hence mechanisms of action of targeted phototherapy systems are similar to those in conventional UVB/UVA therapy [2, 5-8]. Ultraviolet light has a spectrum which is divid- ed into 3 parts according to their wavelengths, namely UVC with the shortest wavelength (200-290 nm), UVB with the intermediate wavelength $(290-320 \mathrm{~nm})$ and UVA with the longest wavelength (320-400 nm). Ultraviolet A is then divided into UVA1 (340-400 nm) and UVA2 $(320-340 \mathrm{~nm})[9,10]$. The light sources include broadband UVB (BB-UVB) with a wavelength of $290-320 \mathrm{~nm}$ and a peak at $313 \mathrm{~nm}$, narrowband UVB (NB-UVB) with a wavelength of 311-313 nm, UVA (320-400 nm, peak at $355 \mathrm{~nm}$ ), and UVA1 (340$400 \mathrm{~nm}$, peak at $365 \mathrm{~nm}$ ). Excimer laser, which emits monochromatic UV light, has various wavelength ranges depending on the molecules used. Especially in the field of dermatology, $\mathrm{XeCl}$ laser with a wavelength of $308 \mathrm{~nm}$ is used. Various mechanisms have been found, and it was proposed that phototherapy can give either a systemic or a local effect. Ultraviolet $B$ rays have shorter wavelengths, so they do not penetrate as deeply as UVA rays do, but UVB rays have more energy. Ultraviolet B phototherapy's primary effect is on the function of keratinocytes and Langerhans cells. The effectiveness of UVB therapy in psoriasis depends especially on its antiproliferative effects. The decrease of pruritus after treatment with both BB-UVB and NB-UVB is caused by cell mast apoptosis [11]. In the use of targeted BBUVB phototherapy, NBUVB and excimer laser, T cell apoptosis was found [12-14]. The apoptosis mechanism may be caused by the damage of the epidermis and dermis cells, which are susceptible to UV light exposure. Ultraviolet B rays cause DNA damage and formation of pyrimidine dimmers [15]. In addition to $T$ cell apoptosis, UVB radiation triggers changes in cytokine production, local immunosuppression and stimulation of melanocyte-stimulating hormone (MSH), and increases migration, proliferation of melanocytes and melanogenesis [16, 17]. A twostep effect of NB-UVB has been proposed - both of them may occur simultaneously though. Firstly, there is immunomodulation (local as well as systemic), leading to downregulation of the immune attack against melanocytes. Subsequently, the melanocytes are stimulated to migrate to the epidermis and synthesize melanin [18]. NB-UVB phototherapy increases synthesis of interleukin-1 (IL-1), tumor necrosis factor- $\alpha$ (TNF- $\alpha$ ) and leukotriene-4 (LTC-4), and these cytokines induce melanocyte mitogenesis, melanogenesis and melanocyte migration. However, the roles of IL-1 and TNF- $\alpha$ in melanogenesis are controversial and contradictory, as has been observed in some studies. It was proposed that TNF- $\alpha$ inhibits the expression and activity of tyrosinase, the key enzyme in melanin synthesis. This inhibition of melanogenesis induced by TNF- $\alpha$ is secondary to activation of nuclear-factor $\mathrm{\kappa B}$ [19]. Interleukin-1 stimulates synthesis of endothelin-1, which is mi- 
togenic and melanogenic. The contradiction is that IL-1 $\beta$ has been found to reduce proliferation of melanocytes and melanogenesis, while IL-1 $\beta$ reduces melanocyte tyrosinase activity without any effect on proliferation [20]. It was also observed that the increase of expression of endothelin-1, IL-1 and tyrosinase in human keratinocytes in vivo and in vitro after UVB irradiation suggested the possible mechanism of repigmentation [21]. Release of prostaglandins $\left(\mathrm{PGE}_{2}\right.$ and $\left.\mathrm{PGF}_{2}\right)$ is another mechanism of action of phototherapy [22]. Prostaglandin $\mathrm{E}_{2}$ is synthesized in the skin and regulates melanocyte and Langerhans cell function, and promotes melanocyte mitogenesis [23]. Ultraviolet A has a longer wavelength, so it can reach the dermis and have an effect on fibroblasts, dermal dendritic cells, endothelial cells, $\mathrm{T}$ lymphocytes in the dermis and granulocytes. In atopic dermatitis, UVA is shown to cause apoptosis of T helper cells in the skin with eczema lesions through the FAS/FAS ligand system [24]. In addition, UVA and UVA1 irradiation may also reduce histamine release by basophils and mast cells [25]. The combination of UVA and psoralen (PUVA) has a more complex mechanism. Psoralen undergoes intercalation in the double-stranded DNA. Ultraviolet A exposure causes the formation of a 3,4 or $4^{\prime}, 5^{\prime}$ cyclobutane monoadduct with pyrimidine bases on a single photon absorption. The double helix DNA then undergoes a crosslinking process when the second light photon is absorbed by 2 monoadducts forming a bifunctional adduct. DNA replication is inhibited by the cross-linking, resulting in cell cycle disruption and decreased epidermal proliferation. Once psoralen is excited by the photons, it can react with oxygen molecules to form reactive oxygen species (ROS), which can cause mitochondrial dysfunction and apoptosis of Langerhans cells, keratinocytes and lymphocytes. Both UVA and UVB cause decreased expression of intercellular adhesion molecule 1 (ICAM-1) and increased levels of immunosuppressive cis-urocanic acid that can depress the cellular immune response and inhibit Langerhans cell activities [26]. Although the mechanism of action of targeted phototherapy is similar to the mechanism of action of conventional UVB/UVA phototherapy, it is thought to be more aggressive because the dose given can be higher than the erythemogenic dose, which results in greater efficacy due to its ability to deliver the energy to the deeper dermis layer [27-33].

\section{ADVANTAGES OF TARGETED PHOTOTHERAPY OVER CONVENTIONAL PHOTOTHERAPY}

Several advantages have been claimed for targeted phototherapy: exposure of involved areas only and sparing of uninvolved areas, thus minimizing acute side effects such as erythema and long-term risk of skin cancer over unaffected skin; quick delivery of energy and thereby shortened duration of treatment; delivery of higher doses (super-erythemogenic doses) of energy because uninvolved areas are not exposed; these higher doses of energy can be delivered selectively to the lesions, thereby enhancing efficacy and achieving a faster response; shortening of the duration of treatment, leading to less frequent visits to the clinic, which is more convenient for the patient; the maneuverable hand piece allows treatment of difficult areas such as scalp, nose, genitals, oral mucosa, ear, etc; easy administration for children as delivery is hand-held, and it also occupies less space [30].

\section{DISADVANTAGES OF TARGETED PHOTOTHERAPY OVER CONVENTIONAL PHOTOTHERAPY}

Targeted phototherapy devices have certain disadvantages: They are more expensive. Also, they are not adequate to treat extensive areas in view of the cost of treatment and time involved in treatment. They are not recommended for use if lesions cover more than $10 \%$ of the body area $[30,31]$.

\section{CONVENTIONAL PHOTOTHERAPY}

In one study, after treating vitiligo with NB-UVB administered as monotherapy 3 times a week [34], 5 of the 7 patients achieved more than $75 \%$ repigmentation with a mean of 19 treatments, whereas the remaining 2 patients had $50 \%$ and $40 \%$ repigmentation after 46 and 48 treatments respectively. In another study, higher success rates were observed with NBUVB (63\%) than with oral PUVA (51\%) [35]. As in the western population, NB-UVB phototherapy produces a cosmetically good color match in Indian patients [36]. Its distinct advantages over PUVA include the lack of psoralen-related side effects and precautions, cosmetically better color match, and its safety in children. However, the relative stability of NB-UVB induced repigmentation over PUVA, its maximum safe duration and cumulative dose allowed still remain to be determined.

The NB-UVB lamp was developed as a "new" UVB phototherapy source with an emission spectrum within the therapeutic waveband for psoriasis phototherapy. NB-UVB phototherapy has a higher ratio of therapeutic to erythemogenic activity, resulting in increased efficacy, reduced incidence of burning and longer remission. Results from two therapeutic action spectroscopy studies indicated that wavelengths of the range 295-320 nm are effective in 
clearing psoriasis, whereas shorter wavelengths are more erythemogenic, and wavelengths longer than 320 are less therapeutic $[37,38]$. Subsequent clinical studies have tended to report significantly greater improvement of psoriasis with NB-UVB including reduced incidence of burning episodes, increased efficacy and longer remission when compared with broad band sources [39]. When NB-UVB phototherapy and PUVA were compared, there was little overall difference in efficacy $[40,41]$.

Prophylactic low dose NB-UVB has been found to be useful in various predominantly UVA induced photosensitivity disorders such as polymorphic light eruption, actinic prurigo, hydroa vacciniforme and cutaneous porphyrias by providing a 'hardening photoprotective' effect. A typical course involves 10-15 treatments given in early spring [42]. We have also observed a beneficial role of NB-UVB in patients with airborne contact dermatitis to Parthenium hysterophorus, a frustrating problem for both the patient and the physician [43].

\section{NEWER/TARGETED PHOTOTHERAPY}

\section{Excimer laser/excimer light (308 nm)}

The various uses of excimer laser include palmoplantar pustular psoriasis, plaque-type psoriasis, nail psoriasis, chronic atopic dermatitis of the hands, non-atopic dermatitis of the hands and alopecia areata. The common side-effects include intense erythema and, more rarely, blisters, but these are usually well tolerated [32].

Nisticò et al. [32] described different applications of monochromatic excimer light in skin diseases in 152 patients with stable and localized plaque psoriasis, 47 with palmoplantar psoriasis, 7 with palmoplantar pustulosis, 32 with vitiligo, 11 with prurigo nodularis, 9 with mycosis fungoides stage Ia, 8 with alopecia, 5 with localized scleroderma, 5 with genital lichen sclerosus, and 3 with granuloma annulare. The treatment produced complete remission in more than $50 \%$ of patients with plaque psoriasis and palmoplantar dermatoses, respectively, complete remission in all patients affected by mycosis fungoides, excellent repigmentation in one third of vitiligo patients, hair regrowth in three patients with alopecia areata, an overall improvement in prurigo nodularis, a partial remission in patients affected by localized scleroderma, and a complete remission in most of the patients with genital lichen sclerosus and granuloma annulare [33].

\section{Dualight}

Previously called Theralight TM, Inc., it emits both UVA radiation in the range $330-380 \mathrm{~nm}$ and
UVB in the range $290-330 \mathrm{~nm}$ with a peak at $303 \mathrm{~nm}$ [5]. The system has a 2-meter long fiber-optic delivery system, with a spot size of $4 \mathrm{~cm}^{2}$. UVA intensity is $10-550 \mathrm{~mW} / \mathrm{cm}^{2}$ for a $3.63-\mathrm{cm}^{2}$ exit aperture, while UVB intensity is $50-250 \mathrm{~mW} / \mathrm{cm}^{2}$ for a $3.63-\mathrm{cm}^{2}$ exit aperture.

\section{B clear targeted photoclearing system}

The B clear system is mercury-based noncoherent UVB radiation with a therapeutic wavelength of $290 \mathrm{~nm}$ to $320 \mathrm{~nm}$ and pulse width of $0.5 \mathrm{~s}$ to $2.0 \mathrm{~s}$. Fluence ranges from 50 to $800 \mathrm{~mJ} / \mathrm{cm}^{2}$ in increments of $10 \mathrm{~mJ} / \mathrm{cm}^{2}$. Its disadvantage is that only the UVB range is available, unlike Dualight, which delivers both UVA and UVB ranges [2, 44].

\section{Photodynamic therapy}

Photodynamic therapy (PDT) involves the use of photochemical reactions mediated through the interaction of photosensitizing agents, light, and oxygen for the treatment of malignant or benign diseases. Photodynamic therapy is a 2-step procedure. In the first step, the photosensitizer is administered to the patient by one of several routes (e.g., topical, oral, intravenous), and it is allowed to be taken up by the target cells. The second step involves the activation of the photosensitizer in the presence of oxygen with a specific wavelength of light directed toward the target tissue. Then there occurs a sunburn reaction, which usually heals within 4-8 weeks. Because the photosensitizer is preferentially absorbed by hyperproliferative tissue and the light source is directly targeted at the lesional tissue, photodynamic therapy achieves dual selectivity, minimizing damage to adjacent healthy structures. The photosensitizers are aminolevulinic acid (ALA) and methyl aminolevulinate (MAL), porfimer sodium (Photofrin), benzoporphyrin derivative monoacid ring $\mathrm{A}$, tin ethyl etiopurpurin, and lutetium texaphyrin [45-48].

Light at a wavelength corresponding to a peak of the porphyrin excitation spectrum in tissues is used. The Soret band (approximately $405-420 \mathrm{~nm}$ ) is the most important excitation peak for protoporphyrin IX and is included in the spectral output of the US Food and Drug Administration (FDA)-approved Blu-U device, which is used with ALA. Another peak in the excitation spectrum for porphyrins includes red light at approximately $635 \mathrm{~nm}$, which is targeted by different devices, including those approved to be used with MAL [34, 36-38].

Light sources used in PDT include laser and nonlaser light. Laser light has the advantages of being [45]: monochromatic (exactly one color/wavelength that corresponds to the peak absorption of the photosensitizing agent); coherent (able to focus light waves 
at a specific site); intense (high irradiance allowing for shorter treatment times).

The only FDA-approved indication for ALA photodynamic therapy and MAL photodynamic therapy in dermatology is currently the treatment of actinic keratoses (AKs). Common off-label uses include the treatment of $\mathrm{BCC}$, photoaging, acne vulgaris, and Bowen disease [49-51].

Side effects of PDT are due to hypersensitivity to light of treated areas. The photosensitivity usually lasts about $24 \mathrm{~h}$ (depending on the specific agent). Side effects may include [45]: burning/stinging sensation; swelling and redness; crusting; pruritus; peeling and blisters; skin infections.

The treated area should be protected from light exposure using a dressing. A local anesthetic such as lignocaine (lidocaine) spray may be applied to the treatment area before or during stage 2 of the procedure to help relieve pain [51].

The author's experience is that although excimer light is effective for treatment of stable localized vitiligo and psoriasis, its efficacy is limited for treatment of alopecia areata.

\section{References}

1. Weichenthal M., Schwarz T.: Phototherapy: how does UV work? Photodermatol Photoimmunol Photomed 2005, 21, 260-266.

2. Mysore V.: Targeted phototherapy. Indian J Dermatol Venereol Leprol 2009, 75, 119-125.

3. Diffey B.L.: Ultraviolet phototherapy of skin diseases. Medical Engineering and Physics in Medicine in the New Millennium. Institute Physics and Engineering in Medicine 2000, 65-67.

4. Huriyah S., Budiyanto A.: Targetted phototherapy for skin diseases. J Med Sci 2012, 44, 117-124.

5. Young A.R., Chadwick C.A., Harrison G.L., Nikaido O., Ramsden J., Potten C.S.: The similarity of action spectra for thymidine dimmers in human epidermis and erythema suggests that DNA is the chromophore for erythema. J Invest Dermatol 1998, 111, 982-988.

6. Cooper K.D.: Cell mediated immunosuppressive mechanisms induced by UV radiation photochemistry and photobiology. Photochem Photobiol 1996, 63, 400-405.

7. Yaron I., Yaron R., Oluwole S.F., Hardy M.A.: UVB radiation of human derived peripheral blood lymphocytes induces apoptosis but not T cell anergy. Cell Immunol 1996, $168,258-266$.

8. Freeman S.E., Gange R.W., Sutherland J.C., Matzinger E.A., Sutherland B.M.: Production of pyrimidine dimmers in DNA of human skin exposed in situ to UVA radiation. J Invest Dermatol 1987, 88, 430-433.

9. Krutmann J., Morita A.: Therapeutic photomedicine: phototherapy. [in:] Fitzpatrick's dermatology in general medicine. K. Wolff, L.A. Goldsmith, S.I. Katz, B.A. Gilchrest, A.S. Paller, D.J. Lefferll (eds.). 7th ed. The McGraw-Hill Company, New York, 2008, 2243-2249.

10. Sage R.J., Lim H.W.: UV-based therapy and vitamin D. Dermatol Ther 2010, 23, 72-81.

11. Szepietowski J.C., Morita A., Tsuji T.: Ultraviolet B induces mast cell apoptosis: a hypothetical mechanism of ultraviolet B for ureamic pruritus. Med Hypotheses 2002, $58,167-170$.

12. Ozawa M., Ferenczi K., Kikuchi T., Cardinale I., Austin L.M., Coven T.R., et al.: 312-nanometer ultraviolet B light (narrow-band UVB) induces apoptosis of T cells within psoriatic lesions. J Exp Med 1999, 189, 711-718.

13. Hassan N.F.M., Soleiman A.N.: $308 \mathrm{~nm}$ excimer laser induces apoptosis of T cells within psoriatic lesions. J Egypt Wom Dermatol Soc 2006, 3, 19-25.

14. Bianchi B., Campolmi P., Mavilia L., Danesi A., Rossi R., Cappugi P.: Monochromatic excimer light (308 nm): an immunohistochemical study of cutaneous T cells and apoptosis-related molecules in psoriasis. JEADV 2003, 17, 408-413.

15. Kvam E., Tyrrell R.M.: Induction of oxidative DNA base damage in human skin cells by UV and near visible radiation. Carcinogenesis 1997, 18, 2379-2384.

16. Wu C.S., Yu C.L., Wu C.S., Lan C.C., Yu H.S.: Narrowband ultraviolet-B stimulates proliferation and migration of cultured melanocytes. Exp Dermatol 2004, 13, 755-763.

17. Van Schanke A., Jongsma M.J., Bisschop R., van Venrooij G.M.C.A., Rebel H., de Gruijl F.R.: Single UVB overexposure stimulates melanocyte proliferation in murine skin, in contrast to fractionated or UVA-1 exposure. J Invest Dermatol 2005, 124, 241-247.

18. Norris D.A., Horikawa T., Morelli J.G.: Melanocyte destruction and repopulation in vitiligo. Pigment Cell Res 1994, 7, 193-203.

19. Englaro W., Bahadoan P., Bertolotto C., Buscà R., Dérijard B., Livolsi A., et al.: Tumor necrosis factor-alpha mediated inhibition of melanogenesis is dependent on nuclear factor kappaB activation. Oncogene 1999, 18, 1553-1559.

20. Swope V.B., Sauder D.N., McKenzie R.C., Sramkoski R.M., Krug K.A., Babcock G.F., et al.: Synthesis of interleukin-1alpha and 1beta by normal human melanocytes. J Invest Dermatol 1994, 102, 749-753.

21. Imokawa G., Miyagishi M., Yada Y.: Endothelin 1 as a new melanogen: coordinated exposure of its gene and the tyrosinase gene in UVB exposed human epidermis. J Invest Dermatol 1995, 105, 32-37.

22. Pentland A., Mahoney M.: Keratinocyte prostaglandin synthesis is enhanced by IL-1. J Invest Dermatol 1990, 94, 43-46.

23. Parsad D., Pandhi R., Dogra S., Pandhi R.: Topical prostaglandin analogue (PGE2) in vitiligo - a preliminary study. Int J Dermatol 2002, 41, 942-945.

24. Morita A., Werfel T., Stege H., Ahrens C., Karmann K., Grewe M., et al.: Evidence that singlet oxygen induced human $\mathrm{T}$ helper cell apoptosis is the basic mechanism of ultraviolet-A radiation phototherapy. J Exp Med 1997, 186, 1763-1768.

25. Kronauer C., Eberlein-Konig B., Ring J., Behrendt H.: Influence of UVB, UVA and UVA1 irradiation on histamin release from human basophils and mast cells in vitro in the presence and absence of antioxidants. Photochem Photobiol 2003, 77, 531-534.

26. Norval M., Gibbs N.K., Gilmour J.: The role of urocanic acid in UV-induced immunosuppression: recent advances (1992-1994). Photochem Photobiol 1995, 62, 209-217.

27. Spencer J.M., Hadi S.M.: The excimer lasers. J Drugs Dermatol 2004, 3, 522-525.

28. Grimes P.E.: Advances in the treatment of vitiligo: targeted phototherapy. Cosm Dermatol 2003, 16, 18-22.

29. Spencer J.M., Nossa R., Ajmeri J.: Treatment of vitiligo with the 308-nm excimer laser: a pilot study. J Am Acad Dermatol 2002, 46, 727-731.

30. Yaron I., Yaron R., Oluwole S.F., Hardy M.A.: UVB radiation of human derived peripheral blood lymphocytes in- 
duces apoptosis but not T cell anergy. Cell Immunol 1996 $168,258-266$

31. Aubin F., Vigan M., Puzenat E., Blanc D., Drobacheff C., Deprez P., et al.: Evaluation of a novel 308-nm monochromatic excimer light delivery system in dermatology: a pilot study in different chronic localized dermatoses. Br J Dermatol 2005, 152, 99-103.

32. Nisticò S.P., Saraceno R., Schipani C., Costanzo A., Chimenti S.: Photomedicine and laser. Surgery 2009, 27, 647-654.

33. Scherschun L., Kim J.J., Lim H.W.: Narrow-band ultraviolet $\mathrm{B}$ is a useful and well-tolerated treatment for vitiligo. J Am Acad Dermatol 2001, 44, 999-1003.

34. Njoo M.D., Spuls P.I., Bos J.D.,Westerhof W., Bossuyt P.M.: Nonsurgical repigmentation therapies in vitiligo: metaanalysis of the literature. Arch Dermatol 1998, 134, 15321540.

35. Kanwar A.J., Dogra S., Parsad D., Kumar B.: Narrow band UVB for treatment of vitiligo: an emerging effective and well-tolerated therapy. Int J Dermatol 2005, 44, 57-60.

36. Trembath R.C., Clough R.L., Rosbotham J.L., Jones A.B., Camp R.D., Frodsham A., et al.: Identification of a major susceptibility locus on chromosome $6 p$ and evidence for further disease loci revealed by a two stage genome-wide search in psoriasis. Hum Molec Genet 1997, 6, 813-820.

37. Bos J.D., Hulsebosch H.J., Krieg S.R., Bakker P.M., Cormane R.H.: Immunocompetent cells in psoriasis: in situ immunophenotyping by monoclonal antibodies. Arch Dermatol Res 1983, 275, 181-189.

38. Morganroth G.S., Chan L.S., Weinstein G.D., Voorhees J.J. Cooper K.D.: Proliferating cells in psoriatic dermis are comprised primarily of $\mathrm{T}$ cells, endothelial cells, and factor XIIIa perivascular dendritic cells. J Invest Dermatol 1991, 96, 333-340.

39. Van Welden H., Baart de la Faille H., Young E., Van der Leun J.C.: A new development in UVB phototherapy for psoriasis. Br J Dermatol 1988, 119, 11-19.

40. Fischer T.: UV-light treatment of psoriasis. Acta Derm Venereol 1976, 56, 473-479.

41. Collin P., Ferguson J.: Narrow-band UVB (TL-01) phototherapy: an effective preventative treatment for the photodermatoses. Br J Dermatol 1995, 132, 956-963.

Received: 4 X $2014 \mathrm{r}$.

Accepted: 7 I $2015 \mathrm{r}$.
42. Dogra S., Parsad D., Handa S.: Narrowband ultraviolet B in airborne contact dermatitis: a ray of hope! Br J Dermatol 2004, 150, 373-374.

43. Gilles P.R.: Technical evaluation of fibre optically delivered light for lesion targeted high dosage UVB phototherapy. B-clear application note 2. Lumenis inhouse publication 2002.

44. Wiegell S.R., Wulf H.C., Szeimies R.M., Basset-Seguin N., Bissonnette R., Gerritsen M.J., et al.: Daylight photodynamic therapy for actinic keratosis: an international consensus: International Society for Photodynamic Therapy in Dermatology. JEADV 2012, 26, 673-679.

45. Bissonette R., Bergeron A., Liu Y.: Large surface photodynamic therapy with aminolevulinic acid: treatment of actinic keratoses and beyond. J Drugs Dermatol 2004, 3 (1 Suppl.), S26-S31.

46. Piacquadio D.J., Chen D.M., Farber H.F., Fowler J.F., Glazer S.D., Goodman J.J., et al.: Photodynamic therapy with aminolevulinic acid topical solution and visible blue light in the treatment of multiple actinic keratoses of the face and scalp: investigator-blinded, phase 3, multicenter trials. Arch Dermatol 2004, 140, 41-46.

47. Babilas P., Karrer S., Sidoroff A., Landthaler M., Szeimies R.M.: Photodynamic therapy in dermatology: an update. Photodermatol Photoimmunol Photomed 2005, 21, 142-149.

48. Klein A., Babilas P., Karrer S., Landthaler M., Szeimies R.M.: Photodynamic therapy in dermatology: an update 2008. J Dtsch Dermatol Ges 2008, 6, 839-846.

49. Babilas P., Schreml S., Landthaler M., Szeimies R.M.: Photodynamic therapy in dermatology: state-of-the-art. Photodermatol Photoimmunol Photomed 2010, 26, 118-132.

50. Kostović K., Pastar Z., Ceović R., Mokos Z.B., Buzina D.S., Stanimirović A.: Photodynamic therapy in dermatology: current treatments and implications. Coll Antropol 2012, 36, 1477-1481.

51. Morton C.A., McKenna K.E., Rhodes L.E.: Guidelines for topical photodynamic therapy: update. Br J Dermatol 2008, $159,1245-1266$ 